\title{
WHAT DRIVES OUTWARD FDI OF CHINA? A REGIONAL ANALYSIS
}

\author{
Kefei You* \\ University of Greenwich, UK
}

\begin{abstract}
China has become one of the world's biggest source of outward FDI in the past decade. A fair amount of literature have emerged explaining home determinants of China's outward FDI at country- and firm-level. Our study attempts to examine drivers of China's overseas investment from a fresh angle - China's regional outward FDI. While central outward FDI is made by large central firms which are directly supervised and managed by the State Council, regional outward FDI is from regional firms that are owned by regional governments and the private sector. The rising importance of regional outward FDI compared with central outward FDI warrants a thorough investigation on the former. We propose a theoretical framework that incorporates an extended Investment Development Path (IDP) theory, home locational constraints, policy incentives and geographic factors. Many variables examined in our study have never been introduced previously to analyse China's outward FDI. Empirically, we employ the Bayesian Averaging Maximum Likelihood Estimates method to address model uncertainty. This is the first time this method is used in FDI literature. All proposed theories (except the geographic factors) are found to capture important perspectives explaining China's regional outward FDI. Our results particularly highlight the importance of government policies (presence of SOEs, willingness to approve local outward FDI, and investment in R\&D), but do not support the original IDP hypothesis that outward investment is automatically generated as income grows. We found two variables based on the extended IDP theory, namely trade openness and agglomeration effect to be robust determinants. Pollution is the only home locational constraint that is robust, and geographic factors have little impact on regional outward FDI. Our findings have both regional and central policy implications. Central policy makers need to recognise that local outward investment may response to different set of factors compared with central investment abroad and take this into account when setting outward FDI policies. At regional level, our study provides direct reference on tools local government can employ to facilitate outward investment.
\end{abstract}

JEL Classification: F21, R11, C11, C23

Keywords: China, regional outward FDI, home determinants, extended IDP theory, home locational constraints, government policies, Bayesian.

Contact Author's Email Address: k.you@greenwich.ac.uk

\section{INTRODUCTION}

Since the implementation of the reform and opening up policy in 1978, China has been attracting foreign direct investment (FDI) from the rest of the world and has become one of the world's largest FDI destinations. In the past two decades, however, a new trend has emerged - there has been a dramatic increase in China's outward FDI (OFDI), especially after the national policy of encouraging domestic investment to "go out" of China in 1999 (see Table 1). In 2011, China was the world's 6th largest source of FDI. Alongside the impressive growth of overseas investment, a fair amount of literature has emerged explaining the determinants of China's OFDI at country- (e.g. Liu et al., 2005; Buckley et al., 2007; Cheng \& Ma, 2007; Cheung \& Qian, 2009; Wei \& Alon, 2010; Tolentino, 2010; Kolstad \& Wigg, 2012), industry(e.g. Amighini et al., 2011) and firm-level (e.g. Amighini et al., 2012; Wang et al., 
2012). A summary of these studies is presented in Table 2. Compared with previous analysis, our study attempts to investigate drivers of China's overseas investment from a fresh angle - China's regional OFDI. While country-level analysis may ignore heterogeneity across Chinese regions, a regional level study would enable us to examine whether such heterogeneity had contributed to various level of OFDI across the regions. Specifically, out study employs regional level data and focus on homecountry drivers of outward FDI. We propose a comprehensive multi-level theoretical framework to investigate home drivers of China's regional OFDI. It builds on four different, but complementary, theoretical explanations, namely the extended Investment Development Path (IDP) theory, home locational constraints, policy incentives, and geographic factors. We employ the recently developed panel Bayesian Averaging of Maximum Likelihood Estimates (BAMLE) by Moral-Benito (2012) to deal with model uncertainty, an issue arises when competing theories are incorporated within a compressive model.

\section{THE THEORETICAL FOUNDATIONS}

After reviewing a range of theoretical FDI models, Faeth (2009) conclude that different theories do not necessarily replace each other, but explain different aspects of the same phenomenon, and hence that FDI should not be explained by single theories but more broadly a combination of them. Buckley et al. (2007) and Wang et al. (2012) have done so for China's OFDI at country- and firm-level, respectively. For our regional analysis, we propose a comprehensive theoretical framework that combines four complementary theoretical explanations, namely the extended IDP theory, home locational constraints, policy incentives, and geographic factors.

\section{The Extended Investment Development Path Theory}

Dunning's (1981) Investment Development Path (IDP) theory has provided a longstanding explanation of OFDI from many countries. The basic hypothesis of the IDP theory is that as a country develops, the localisation advantages in host country and the ownership advantages in home country multinational firms will undergo change as host countries themselves develop into ownership advantages and thus they now generate OFDI and in turn seek localisation advantages elsewhere in overseas countries. However, despite having successfully explained OFDI from many developed countries, the IDP theory has been put into question when applied to developing and transitional economies. For instance, Erdilek (2003) find that some developing countries are unable to carry out international activities or fail to develop localisation advantages despite moving through economic development stages.

Thus, as the world's largest developing economy, does China's OFDI indeed follows the IDP theory or it represents a major exception to it, especially given China's unique economic development path and the role played by its governments in the market-oriented economy?

\section{Home Locational Constraints}

Economic reforms and liberalisation that have widely occurred in developing and transitional economies often lead to surges of OFDI as domestic firms, for the first time, are allowed to escape rigid home market constraints and to invest abroad. Under such circumstance, OFDI from developing and transitional economies is not driven by ownership advantages associated with economic development, but by 
home localisation disadvantages (Svetličič, 2003). Following UNCTAD (2006), home locational conditions are ones that influence companies to move abroad and are mainly consist of the following types: market and trade conditions, costs of production, and local business conditions. For developing and transitional economies, these conditions often form home localisation disadvantages for domestic firms.

Some empirical examples that have confirmed these three common home locational constraints as pushing factors that lead developing-country firms to go overseas include UNCTAD (2003) for the limited size of domestic markets; Brooks \& Mirza (2005) for the rising costs of home production; Farrell et al. (2005) for intense competition from both local and foreign firms. Therefore, in our study, we include home locational constraints as an important theoretical explanation of China's regional OFDI.

\section{Policy Incentives}

In a recent literature review by Faeth (2009), policy incentives have been found to form an important category of theoretical model explaining firms' overseas investment decisions. Specifically, governments can influence the firm's choice between domestic production, licensing or FDI, the firm's location choice, the firm's choice to stay or to expand, etc. Developing economies often feature the significant government involvement in business affairs despite the emergence of market system. For instance, Le \& Zak (2006) find that policy uncertainty is an important driving factor of capital outflow from developing countries. Correspondingly, home government policy is regarded as an essential part of an action plan for investment in less developed countries proposed by UNCTAD (2011).

In the case of China, only a few policy variables (e.g., liberalisation policy in 1992 in Buckley et al. (2007), interest rate policy and exchange rate policy in Wei \& Alon (2010) and Tolentino (2010), government support in certain industries in Wang et al. (2011)) have been employed by previous analysis as home determinants of China's OFDI. In our study, we not only examine a wide range of central polices, but also introduce important local governments’ policies to form a third explanation to China's regional OFDI.

\section{Geographic Factors}

Gallup et al. (1999) emphasise that geography continues to play an important role for economic development, alongside the importance of economic and political institutions. Geographic factors of host countries (e.g., landlocked or island economy) have been widely employed to explain locational decision of FDI. In the case of China, it is widely recognised that there is geographic heterogeneity amongst its regions. For instance, some regions are located in the coastal areas while others in the inland areas; some regions are richer in natural resources than others; etc. To explicitly account for this regional heterogeneity, we introduce geographic factors to form the final theoretical explanation of China's regional OFDI.

\section{HYPOTHESES DEVELOPMENT}

\section{An Extended Investment Development Path Theory For Chinese Regions}

In the original IDP theory, the level of economic development is explicitly measured by GDP per capita. For Chinese regions, following Liu et al. (2005) and Wei \& Alon 
(2010), we also employ an extended IDP theory, i.e., incorporating five economic variables (i.e., human capital, trade openness, technology, inward FDI and foreign trade surplus1) in addition to Gross Regional Product (GRP) per capita to reflect the ownership advantage of regional overseas investors.

In addition to above five economic variables, agglomeration economies arise from the presence of other firms, other industries, as well as from the availability of skilled labour force (Venables, 1996). Previous OFDI from a home country can create positive externalities, a form of ownership advantage, such as factories and production lines that have already been set up, and hence it encourages further OFDI flows. As pointed out by Krugman (1997), FDI tends to follow previous investment. Cheung \& Qian (2009) find overwhelming evidence of agglomeration effects for China's national OFDI. Similarly, the agglomeration effects are also applicable for OFDI at regional level. Hypothesis 1: The level of China's regional OFDI is positively related to (a) GRP per capita, (b) human capital, (c) inward FDI, (d) international trade, (e) foreign trade surplus, (f) technology capability, (g) agglomeration effects.

\section{Regional Locational Constraints}

As mentioned earlier, we examine three types of locational constraints of the home economy, namely market and trade conditions (e.g., limited home market due to insufficient domestic consumption), costs of production (e.g., rising cost of labour) and local business conditions (e.g., competition from foreign firms). To our knowledge, none of these home locational constraints has been empirically examined as important home determinants of China's OFDI at national or regional level.

In addition to competition from foreign enterprises, inadequate infrastructure is also a form of adverse business conditions at home that may push domestic investment abroad (UNCTAD, 2006). Similarly, pollution is also a form of adverse business condition for Chinese firms, especially given that it has led to gradually tightening environmental regulations2. Hypothesis 2: the level of China's regional OFDI is positively related to (a) cost of labour, (b) foreign competition, (c) pollution, but negatively related to (d) domestic consumption, (e) infrastructure.

\section{Policy Incentives of Chinese Regions}

Following Wei \& Alon (2010) and Tolentino (2010), we include both interest rate and exchange rate as indictors of monetary and foreign exchange policies, respectively. In addition to the above two central polices in monetary and foreign exchange areas, and to better account for the role of both central and local governments, we also include five new central government policies, i.e., credit growth, corporate tax, anti-corruption, rights of the workers, presence of State Owned Enterprises (SOEs), and two regional government policies, i.e., willingness to approve regional OFDI, and investment on research and development (R\&D)3.

Hypothesis 3: The level of China's regional OFDI is positively related to governments' favourable policies towards (a) appreciation of the exchange rate of the RMB, (b) high credit growth, (c) high corporate tax rate, (d) rights of the workers, (e) willingness to approve OFDI, (f) investment on $\mathrm{R} \& \mathrm{D}$, but is negatively related to governments' favourable policies towards (g) high interest rate, (h) anti-corruption effort, and (i) presence of SOEs. 


\section{Regional Geographic Characteristics}

The Chinese territory consists of coastal areas and interior land. The coastal areas cluster in the east and south of China, forming a belt of more developed regions. Porter (1990) argues that advantages gained in clusters can be the foundations of successful internationalisation. These advantages go beyond ones due to the copresence of related firms and institutions (e.g. transportation links and climate) (Swann et al., 1998) to further include labour market pooling, the emergence of specialised input suppliers, and technological and knowledge spill overs (Gupta and Subramanian, 2008).

From a home country perspective, there is also huge heterogeneity in the amount of natural resources stocks each region possesses across China. In resource rich regions, a larger proportion of firms would be serving regional resource industry and would be less pressured to expand abroad compared with ones in regions with little national resource endowment. Hypothesis 4: The level of China's regional OFDI is positively related to (a) geographic location of being coastal regions, but negatively related to (b) natural resource endowment.

\section{BAYESIAN AVERAGING MAXIMUM LIKELIHOOD ESTIMATES (BAMLE) PANEL METHOD}

Various models and theories have proposed a fairly large number of variables as determinants of outward and inward FDI. Several different models may all seem reasonable given the data as they have equal theoretical status but generate different conclusion about the parameters of interest. This issue is referred to as model uncertainty. The Bayesian Averaging of Maximum Likelihood Estimates (BAMLE) method is employed in our study to address such model uncertainty. Our study considers not one but four theoretical explanations of China's regional OFDI and hence requires the issue of model uncertainty arises while conventional regression, cointegration and Generalised Method of Movements (GMM) (see Table 2) are unable to address the issue 4.

In BAMLE framework, a model is formally defined by a likelihood function and a prior density. Supposing that there are $\mathrm{K}$ possible explanatory variables, there will be $2^{\mathrm{K}}$ possible combinations of regressors, or $2^{\mathrm{K}}$ models. All models, denoted by $M_{j}$ for $j=1, \ldots, 2^{K}$, seek to explain $y$, the data. $\theta^{j}$ is the estimated parameters for each model $M_{j}$. The logic of Bayesian inference suggests that Baye's rule is used to derive a probability statement about what we do not know (i.e. whether a model is correct or not) conditional on what we do know (i.e. the data). This implies that the posterior model probability can be used to assess the degree of support for $\mathrm{M}_{\mathrm{j}}$.

The BAMLE approach of Moral-Benito (2012) extends the Bayesian moving average (BMA) methodology mentioned above to a panel data framework and employs averaging maximum likelihood estimates in a Bayesian spirit. In other words, the posterior probability in the standard BMA method can be rewritten as:

$$
\mathrm{E}(\theta \mid \mathrm{y})=\sum_{\mathrm{j}=1}^{2^{\mathrm{K}}} \mathrm{P}\left(\mathrm{M}_{\mathrm{j}} \mid \mathrm{y}\right) \mathrm{E}\left(\theta \mid \mathrm{y}, \mathrm{M}_{\mathrm{j}}\right)
$$

while the BAMLE approach specifies the posterior probability as: 
$\mathrm{E}(\theta \mid \mathrm{y})=\sum_{\mathrm{j}=1}^{2^{\mathrm{K}}} \mathrm{P}\left(\mathrm{M}_{\mathrm{j}} \mid \mathrm{y}\right) \hat{\theta}_{\mathrm{ML}}^{\mathrm{j}}$

where $\hat{\theta}_{\mathrm{ML}}^{\mathrm{j}}$ is the maximum likelihood estimate for $\theta$ in model $\mathrm{j}$.

In a panel data context, for a give model $\mathrm{M}_{\mathrm{j}}$, the estimated econometric model consists of the following equation:

$$
y_{i t}=\alpha y_{i t-\tau}+x_{i t}^{\prime j} \beta^{j}+z_{i}^{\prime j} \gamma^{j}+\eta_{i}+\zeta_{t}+v_{i t} \quad(t=1, \ldots T)(i=1, \ldots N)
$$

and two assumptions:

$$
\begin{gathered}
v_{i t} \mid y_{i t-1} \ldots y_{i 0}, x_{i}^{j}, z_{i}^{j}, \eta_{i} \sim N\left(0, \sigma_{v}^{2}\right) \\
\eta_{i} \mid y_{i 0}, x_{i}^{j}, z_{i}^{j} \sim N\left(\varphi y_{i 0}+\delta^{j} \bar{x}_{i}^{j}, \sigma_{\eta}^{2}\right)
\end{gathered}
$$

where $y_{i t-\tau}$ denotes lags of the dependent variable. $x_{i t}^{j}$ denotes the $k^{j} \times 1$ vector of explanatory variables in model $\mathrm{M}_{\mathrm{j}} \cdot \eta_{\mathrm{i}}$ is the time-invariant component of the error term capturing the unobserved heterogeneity, i.e. it is the individual specific fixed effect. $v_{i t}$ denotes the error tem. $\zeta_{t}$ is time dummies in the model which capture unobserved common factors across countries and therefore cross-sectional dependence is not ruled out. All variables are assumed to be in deviations from their cross-sectional mean. $\mathrm{z}_{\mathrm{i}}^{\mathrm{j}}$ denotes a set of regressors which are time-invariant, such as geographic factors without time variation.

Under assumptions above, Moral-Benito (2012) derives the likelihood function and the posterior model probability for a particular model $\mathrm{M}_{\mathrm{j}}$ using the Bayesian Information Criterion (BIC) approximation (see Moral-Benito (2012) for details). The posterior inclusion probability of a particular variable $h$ is calculated as the sum of the posterior model probabilities for all the models including $\mathrm{h}$ (i.e., $\left.\mathrm{P}\left(\theta_{\mathrm{h}} \neq 0 \mid \mathrm{y}\right)=\sum_{\theta_{\mathrm{h}} \neq 0} \mathrm{P}\left(\mathrm{M}_{\mathrm{j}} \mid \mathrm{y}\right)\right)$.

\section{EMPIRICAL RESULTS}

\section{Data}

Our sample period is 2003-2011. We use annual data for 30 Chinese regions (see Appendix B). Tibet is excluded due to data limitations. Variable measurement and data sources are discussed in Appendix A. The descriptive statistics and correlation matrix are not presented here due to space limitation but are available upon request. All correlation coefficients are below 0.8 , suggesting that there is generally no concern over the correlations amongst determinants.

\section{BAMLE Results}

Recall Equation (3) above:

$y_{i t}=\alpha y_{i t-\tau}+x_{i t}^{\prime j} \beta^{j}+z_{i}^{\prime j} \gamma^{j}+\eta_{i}+\zeta_{t}+v_{i t} \quad(t=1, \ldots T)(i=1, \ldots N)$

To be more specific, $y_{i t}$ is the dependent variable, regional OFDI to Gross Regional Product (GRP) ratio. Vector $\mathrm{x}_{\mathrm{it}}^{\mathrm{j}}$ includes the extended IDP theory variables, home 
locational constraints and government incentives, and vector $\mathrm{z}_{\mathrm{i}}^{\mathrm{j}}$ includes the timeinvariant geographic factors. Note that the lagged dependent variable $\mathrm{y}_{\mathrm{it}-1}$, i.e. OFDI/GRP(-1), measures one of the extended IDP theory factors, namely the agglomeration effect. Also since the BAMLE can accommodate variables without time variation $\mathrm{z}_{\mathrm{i}}$, we are able to include the two geographic factors (location and natural resources endowment) as determinates of China's regional OFDI.

Following Moral-Benito (2012), we set the prior mean model size $m=7$. We also provide results when $\mathrm{m}=5$ to check whether the results are sensitive to the choice of $\mathrm{m}$. The prior inclusion probability $(\xi)$ is determined via:

$\xi=\mathrm{m} / \mathrm{K}$

The Bayesian robustness check adopted in the BAMLE approach is the posterior inclusion probabilities (PIPs) $(\mathrm{h})$ being higher than the prior inclusion probabilities ( $\xi$ ), i.e., $\mathrm{h}>\xi$. Based on Equation (4), $\xi$ in our study is 0.217 when $\mathrm{m}=$ 5 and 0.304 when $\mathrm{m}=7(\mathrm{~K}=23)$. The BAMLE test results are presented in Table 3 . Comparing the two sets of results $(\mathrm{m}=5$ and $\mathrm{m}=7)$, all variables have the same signs, and the same variables are robust irrespective of the choice of $\mathrm{m}$. Specifically, robust home determinants of China's regional OFDI include three government policy variables (presence of SOEs, willingness to approve OFDI and investment on R\&D), two extended IDP theory variables (trade openness and agglomeration effect) and one home locational constraint (pollution).

Looking at our results in Table 3, we first notice that GRP per capita does not appear to be a robust determinant of China's regional OFDI. This is in contrast to the prediction of the original IDP hypothesis, Liu et al. (2005) and Wei \& Alon (2010). Liu et al. (2005) and Wei \& Alon (2010), are at aggregate level. Hence their conclusions may reflect more of the central OFDI given its dominant share. Also, we compete IPD theory with other alternative theories, including the government incentives theory. As suggested by Durán \& Ubeda (2001), OFDI from developing countries may depend less on economic development and more on the activity carried out by governments. Our results suggest this is the case for China's regional OFDI. We now investigate our prime interest, the government policy variables. All three robust policy variables have the expected signs, confirming our predictions set out in Section 3. It is interesting to notice that both regional government policies, namely willingness to approve OFDI and investment on R\&D, are robust. In contrast, only one central government policy, namely presence of SOEs, turns out to be a robust determinant. Our results suggest that both central and local governments have strong influence on China's regional OFDI. More importantly, our results especially highlight the irreplaceable role of the local governments.

On the other hand, six other policy variables, all of which are set by the central government, turn out to have little influence. One of them is the monetary policy, measured by the real base annual lending rate and credit growth set by the Chinese central bank. In parallel with formal banking institutions in China, there is a flourishing informal financial market. The increasing credit demand of China's private enterprises seems to be neglected by the former and hence the latter contributes to closing the gap (Tanaka \& Molnar, 2008). Thriving informal banking sector has greatly weakened the link between monetary policy and the cost and availability of regional firms' financing. In terms of home locational constraints, we find that pollution is a robust determinant of China OFDI, but with a negative sign. As pointed out by Chow (2008), although the central government recognises the use 
of penalties, specific laws are yet to be clarified in areas such as listing detailed polluting activities, estimating their negative externalities, and specifying suitable penalties for violation. Firms may be attracted to stay in China if they are paying lower penalties than the environmental damage they create. Domestic consumption, labour cost and infrastructure are not robust determinates.

Turning to the extended IDP theory, we find there are only two economic variables, namely trade openness and the agglomeration effect, are robust. It seems other four factors have little influence on OFDI at regional level. Both geographic factors have high PIPs, but their posterior standard deviations are bigger than the posterior means. It implies these two variables are associated with OFDI, although we are not able to confirm in which direction. Given the shifting of OFDI sources from eastern to inner and western regions, such results may reflect an overall more balanced distribution of OFDI among regions across China in recent decade.

\section{CONCLUSIONS AND POLICY IMPLICATIONS}

Our study investigates the home determinants of China's regional OFDI. We propose a theoretical framework that integrates four different yet complementary explanations, namely the extended IDP theory, home locational constraints, government incentives and geographic factors. Many variables examined in our study have never been introduced previously to analyse China's OFDI. At empirical level, we employ the BAMLE method to deal with the issue of model uncertainty. This is the first time this method is used in FDI literature.

Overall, our results first confirm all proposed theories (except the geographic factors) capture important perspectives explaining China's regional outward FDI. Second, our findings highlight the importance of government policies variables, namely presence of SOEs, willingness to approve local OFDI and investment in R\&D. More importantly, we find local government policies (such as the latter two policies above) have sizeable influence over regional OFDI. Third, our study does not support the original IDP hypothesis that outward investment is automatically generated as income grows. Fourth, robust variables that based on the extended IDP theory include trade openness and agglomeration effect, and pollution is the only home locational constraint that is robust. Fifth, geographic factors have little impact of regional OFDI.

Our study provides important policy implications. Central policy makers need to recognise that local investment may respond to different set of factors compared with central investment abroad and take these differences into account when setting OFDI policies. For instance, whilst granting lower interest rates on loans to facilitate OFDI may boost overseas investment from centrally-owned enterprises, it may have little impact on investment decisions of local firms as their financing mainly depends on informal financial markets. Hence measures that can lower interest rates in the informal financial markets is needed instead to encourage regional OFDI. At regional level, our study provides direct reference on tools local government can employ to support firms' overseas investment, such as more investment on $\mathrm{R} \& \mathrm{D}$, approving OFDI projects based on their merits rather than local economic growth and unemployment rates, directing certain amount of resources away from SOEs. In addition, local authorities can also help encourage foreign trade, price pollution properly, and carry out firmly penalties on pollution. 


\section{ENDNOTES}

* This paper is written under the Research Fellowship Programme, BOFIT Institute for Economies in Transition, Bank of Finland.

${ }^{1} \mathrm{FX}$ reserves usually refers to the amount of foreign currency the country owns. Given that our analysis is at regional level, we name this variable regional foreign trade surplus. See You and Sarantis (2012) for a review of China's recent FX policies.

${ }^{2}$ In 1989, the first Environment Protection Law was put forward in China. At firm level, in 2006, Corporate Social Responsibility has become a law introduced under the Company Law in China.

${ }^{3}$ Due to space limitation, for more discussion on policy incentive variables that are introduced in Hypothesis 3, please refer to the working paper version of this paper at https:/helda.helsinki.fi/bof/bitstream/handle/123456789/13672/dp1615\%5B1\%5D.pdf?sequen ce $=1$.

${ }^{4}$ Please refer to Moral-Benito (2012) for a discussion on advantages of BAMLE compared with alternative methods such as BACE (Bayesian Averaging of Classical Estimates), BMA (Bayesian Model Averaging) and EBA (Extreme Bounds Analysis). 


\section{APPENDIX A. REGIONAL VARIABLE MEASUREMENT AND DATA SOURCE (2003-2011)}

Outward FDI is measured as the outward FDI divided by gross regional product (GRP). Data is collected from SBCOFDI and CSY. Variable measurement and data source for other variables are listed below. Note that SBCOFDI: Statistical Bulletin of China's Outward Foreign Direct Investment; CSY: China Statistical Yearbook; IFS: International Financial Statistics; CCSY: China City Statistical Yearbook; ACFB: Almanac of China's Finance and Banking; PYC: Procuratorial Yearbook of China; CLSY: China Labour Statistical Yearbook, PBC: People's Bank of China. All price indices have 2005 as the base year $(2005=100)$. All data are at regional level (note that the annual base interest rate set by the central bank and the nominal exchange of CNY/USD are national level data before they were adjusted by regional CPI to obtain the regional real terms). All variables are in natural logarithm except the cost of labour and interest rate.

(1) GRP per capita: Real GRP per capita (nominal GRP adjusted by consumer price index (CPI)) divided by regional population); CSY

(2) human capital: average schooling years of working population (see Wang and Yao (2003) for a similar measurement); CSY

(3) inward FDI: inward FDI divided by GRP; CCSY, CSY

(4) international trade: sum of export and import divided by GRP; CCSY, CSY

(5) foreign trade surplus: export minus import divided by GRP; CCSY, CSY

(6) technology capability: patent applications divided by population; CSY

(7) agglomeration effects: outward FDI of the previous year; SBCOFDI, CSY

(8) cost of labour: growth rate of real average salary (nominal salary adjusted by CPI) per person; CSY

(9) foreign competition: exports from foreign invested enterprises divided by total exports; CSY

(10) pollution: the amount of $\mathrm{CO}_{2}$ emission (standard cubic meter) divided by population; CSY

(11) domestic consumption: household consumption divided by GRP; CSY

(12) infrastructure: number of landlines per person; CSY

(13) RMB exchange rate: real CNY/USD exchange rate (nominal rate adjusted by relative CPI of the US to each Chinese region); IFS, CSY

(14) credit growth: loan growth divided by GRP; ACFB, CSY

(15) corporate tax rate: corporate tax divided by GRP; CCSY, CSY

(16) rights of the workers: number of trade unions divided by population; CLSY, CSY

(17) willingness to approve OFDI: unemployment rate; CSY

(18) investment on R\&D: ratio of regional governments' investment on science and research to total governments' expenditure; CSY

(19) interest rate: annual national base interest rate set by the central bank adjusted by regional CPI to obtain the real regional rates; PBC, CSY

(20) anti-corruption effort : number of registered cases under the direct investigation of the people's procuratorates divided by population; PYC, CSY

(21) presence of SOEs: SOEs' output to GRP (SOEs defined following Duanmu (2012) and Amighini et al.; CSY

(22) Geographic location: one for coastal (non-landlocked) regions (Tianjin, Hebei, Liaoning, Shanghai, Jiangsu, Zhejiang, Fujian, Shandong, Guangdong, Guangxi and Hainan) and zero for interior regions

(23) Natural resources endowment: one for natural resources rich regions (regions with stock in coal higher than regional average) (Shanxi, Inner Mongolia, Anhui, Shandong, Henan, Shaanxi and Xinjiang) and zero for other regions; CSY

\section{APPENDIX B. REGIONS IN CHINA}

There are thirty one regions in China, which include twenty two provinces (Anhui, Fujian, Gansu, Guangdong, Guizhou, Hainan, Hebei, Heilongjiang, Henan, Hubei, Hunan, Jiangsu, 
Jiangxi, Jilin, Liaoning, Qinghai, Shaanxi, Shandong, Shanxi, Sichuan, Yunnan, Zhejiang), five Autonomous Regions (Guangxi, Inner Mongolia, Ningxia, Tibet, Xinjiang) and four Municipalities (Beijing, Chongqing, Shanghai, Tianjin). In our study we include all these regions except Tibet due to data limitations.

TABLE 1. CHINA'S OFDI AT CENTRAL AND REGIONAL LEVELS (MILLION USD)

\begin{tabular}{|l|l|l|l|l|l|l|l|l|l|}
\hline & 2003 & 2004 & 2005 & 2006 & 2007 & 2008 & 2009 & 2010 & 2011 \\
\hline $\begin{array}{l}\text { Total } \\
\text { OFDI }\end{array}$ & 2855 & 5498 & 12261 & 17634 & 26506 & 41859 & 47795 & 60182 & 68584 \\
\hline $\begin{array}{l}\text { Central } \\
\text { OFDI }\end{array}$ & 2098 & 4525 & 10204 & 15237 & 21253 & 35983 & 38193 & 42437 & 45023 \\
\hline $\begin{array}{l}\text { Regional } \\
\text { OFDI }\end{array}$ & 757 & 973 & 2058 & 2397 & 5253 & 5876 & 9603 & 17745 & 23560 \\
\hline $\begin{array}{l}\text { Regional } \\
\text { /Total } \\
\text { OFDI (\%) }\end{array}$ & 26.5 & 17.7 & 16.8 & 13.6 & 19.8 & 14.0 & 20.1 & 29.5 & 34.4 \\
\hline
\end{tabular}


TABLE 2. REVIEW OF RECENT EMPIRICAL ANALYSIS ON DETERMINANTS OF CHINA'S OFDI

\begin{tabular}{|c|c|c|c|c|}
\hline Authors & Level & $\begin{array}{l}\text { Home/ } \\
\text { Host }\end{array}$ & Theoretical Framework & Methodology \\
\hline Liu et al. (2005) & Country & Home & Investment Development Path (IDP) theory & Cointegration and GMM \\
\hline Wei \& Alon (2010) & Country & Home & Extended IDP theory & Partial least square regression) \\
\hline Tolentino (2010) & Country & Home & $\begin{array}{l}\text { Home country-specific macroeconomic factors of China and } \\
\text { India (it is argued that ownership advantages reflect national } \\
\text { economic characteristics) }\end{array}$ & $\begin{array}{l}\text { Vector Autoregression (VAR) } \\
\text { model }\end{array}$ \\
\hline Buckley et al. (2007) & Country & Host & $\begin{array}{l}\text { Three special explanations (capital market imperfections, special } \\
\text { ownership advantages and institutional factors) are nested within } \\
\text { the general theory of the multinational firm (Market-seeking } \\
\text { motive, resources seeking motive, strategic asset seeking motive) }\end{array}$ & $\begin{array}{l}\text { Regression analysis (pooled OLS } \\
\text { and random effect Generalised } \\
\text { Least Squares(GLS)) }\end{array}$ \\
\hline Cheng \& Ма (2008) & Country & Host & $\begin{array}{l}\text { A set of macroeconomic variables are identified based on } \\
\text { literature review and data availability }\end{array}$ & $\begin{array}{l}\text { Regression analysis (on a gravity } \\
\text { model) }\end{array}$ \\
\hline $\begin{array}{l}\text { Cheung \& Qian } \\
\text { (2009) }\end{array}$ & Country & Host & Market-seeking motive, resources seeking motive & Regression analysis \\
\hline $\begin{array}{l}\text { Kolstad \& Wigg } \\
\text { (2012) }\end{array}$ & Country & Host & $\begin{array}{l}\text { Determinants are identified based on conclusions derived from } \\
\text { review of literature and the characteristics of the Chinese } \\
\text { economy }\end{array}$ & Regression analysis \\
\hline Amighini et al. (2011) & Industry & Host & $\begin{array}{l}\text { Market-seeking motive, resources seeking motive, strategic asset } \\
\text { seeking }\end{array}$ & Random effect probit model \\
\hline Wang et al. (2012) & Firm & Home & $\begin{array}{l}\text { A combination of three theoretical frameworks: resource based } \\
\text { view of firms, industrial organisation economy, and institutional } \\
\text { theory (to capture firm, industry, and country level variables } \\
\text { respectively) }\end{array}$ & Regression analysis \\
\hline Amighini et al. (2012) & $\begin{array}{l}\text { Ownership } \\
\text { (SOEs and } \\
\text { private firms) }\end{array}$ & Host & $\begin{array}{l}\text { Market-seeking motive, resources seeking motive, strategic asset } \\
\text { seeking motive }\end{array}$ & $\begin{array}{l}\text { Random effect panel Poisson } \\
\text { model }\end{array}$ \\
\hline
\end{tabular}


TABLE 3. BAMLE APPROACH RESULTS

\begin{tabular}{|c|c|c|c|c|c|c|}
\hline \multirow[t]{2}{*}{ Variables } & \multicolumn{3}{|l|}{$\mathrm{m}=5$} & \multicolumn{3}{|l|}{$\mathrm{m}=7$} \\
\hline & $\begin{array}{l}\text { (PIPs) } \\
\text { (h) }\end{array}$ & PM & PSD & $\begin{array}{l}\text { (PIPs) } \\
\text { (h) }\end{array}$ & PM & PSD \\
\hline \multicolumn{7}{|l|}{ Extended IDP theory } \\
\hline (1) GRP per capita & 0.022 & -0.001 & 0.002 & 0.037 & -0.001 & 0.002 \\
\hline (2) human capital & 0.044 & -0.061 & 0.061 & 0.063 & -0.060 & 0.062 \\
\hline (3) inward FDI & 0.025 & 0.000 & 0.002 & 0.036 & 0.000 & 0.003 \\
\hline (4) international trade & 0.735 & 0.017 & 0.006 & 0.855 & 0.018 & 0.006 \\
\hline (5) foreign trade surplus & 0.095 & -0.006 & 0.006 & 0.130 & -0.006 & 0.006 \\
\hline (6) technology capability & 0.053 & 0.002 & 0.005 & 0.071 & 0.003 & 0.005 \\
\hline (7) agglomeration effects & 1.000 & 0.477 & 0.115 & 1.000 & 0.470 & 0.115 \\
\hline \multicolumn{7}{|l|}{$\begin{array}{l}\text { Home locational } \\
\text { constraints }\end{array}$} \\
\hline (8) cost of labour & 0.024 & 0.000 & 0.000 & 0.038 & 0.000 & 0.000 \\
\hline (9) foreign competition & 0.031 & 0.001 & 0.006 & 0.053 & 0.000 & 0.007 \\
\hline (10) pollution & 0.352 & -0.019 & 0.012 & 0.454 & -0.020 & 0.012 \\
\hline (11) domestic consumption & 0.050 & 0.007 & 0.014 & 0.069 & 0.007 & 0.014 \\
\hline (12) infrastructure & 0.051 & -0.008 & 0.007 & 0.074 & -0.008 & 0.007 \\
\hline \multicolumn{7}{|l|}{ Government incentives } \\
\hline (13) RMB exchange rate & 0.055 & 0.109 & 0.082 & 0.098 & 0.123 & 0.083 \\
\hline (14) credit growth & 0.025 & 0.002 & 0.006 & 0.042 & 0.001 & 0.006 \\
\hline (15) corporate tax rate & 0.186 & 0.014 & 0.007 & 0.199 & 0.013 & 0.007 \\
\hline (16) rights of the workers & 0.118 & -0.021 & 0.012 & 0.197 & -0.023 & 0.013 \\
\hline $\begin{array}{l}\text { (17) willingness to approve } \\
\text { OFDI }\end{array}$ & 1.000 & -0.100 & 0.016 & 1.000 & -0.098 & 0.016 \\
\hline (18) investment on R\&D & 0.309 & 0.030 & 0.016 & 0.401 & 0.030 & 0.016 \\
\hline (19) interest rate & 0.052 & -0.002 & 0.001 & 0.080 & -0.002 & 0.001 \\
\hline (20) anti-corruption effort & 0.044 & -0.004 & 0.004 & 0.065 & -0.004 & 0.004 \\
\hline (21) presence of SOEs & 0.781 & -0.044 & 0.013 & 0.866 & -0.044 & 0.013 \\
\hline \multicolumn{7}{|l|}{ Geographic factors } \\
\hline (22) Geographic location & 0.478 & 0.002 & 0.004 & 0.432 & 0.001 & 0.004 \\
\hline $\begin{array}{l}\text { (23) Natural resources } \\
\text { endowment }\end{array}$ & 0.535 & -0.003 & 0.003 & 0.587 & -0.003 & 0.003 \\
\hline
\end{tabular}

Note: PIPs: Posterior Inclusion Probability; PM: Posterior Mean; PSD: Posterior Standard Deviation. GAUSS algorithm for the BAMLE method is provided by Dr. Moral-Benito. The number of iterations of the algorithm is set at one million. Following Moral-Benito (2012), the Bayesian robustness check adopted in the BAMLE approach is the PIPs $(h)$ being higher than the prior inclusion probabilities ( $\xi$ ), i.e., $h>\xi$. Based on Equation (4), $\xi$ in our study is 0.217 when $m=5$ and 0.304 when $m=7(K=23)$. 


\section{REFERENCES}

Amighini, A, Rabellotti, R, \& Sanfilippo, M. 2011. China's outward FDI: An industry-level analysis of host country determinants. CESifo Working Paper Series, No. 3688.

Amighini, A, Rabellotti R, \& Sanfilippo, M. 2012. Do Chinese SOEs and private companies differ in their foreign location strategies? RSCAS Working Paper, 2012/27, European University Institute.

Assunção, S, Forte, R, \& Teixeira, A. 2011. Location determinants of FDI: a literature review, FEP Working Paper, No. 433, University of Porto.

Brooks, DH, \& Mirza, HR. 2005. Outward FDI from developing Asia. Paper presented at the Asian Development Bank seminar, "Outward Foreign Direct Investment from Asian Developing Countries”, Bangkok, 28-29 November.

Buckley, PJ, Clegg, LJ, Cross, AR, Liu, X, Voss, H., \& Zheng, P. 2007. The determinants of Chinese outward foreign direct investment. Journal of International Business Studies, 38: 499-518.

Cheng, LK, \& Ma, Z. 2007. China's outward FDI: Past and future. School of Economics Working Paper No. 2007706001E, Renmin University, China.

Cheung, YW, \& Qian, XW. 2009. The empirics of China's outward direct investment. CESifo Working Paper Series, No. 2621.

Chow, G. 2008. China's energy and environmental problems and policies. AsiaPacific Journal of Accounting \& Economics, 15(1): 57-70.

Duanmu, JL. 2012. Firm heterogeneity and location choice of Chinese Multinational Enterprises. Journal of World Business, 47: 64-72.

Dunning, JH. 1981. Explaining the international direct investment position of countries: Toward a dynamic and development approach. Weltwirtschaftliches Archiv, 117/5: 30-64.

Durán, J., \& Ubeda, F. 2001. The investment path: A new methodological approach and some theoretical issues. Transnational Corporations, 10(2): 1-34.

Erdilek, A. 2003. A comparative analysis of inward and outward FDI in Turkey. Transnational Corporations, 12(3): 79-105.

Faeth, I. 2009. Determinants of foreign direct investment - a tale of nine theoretical models. Journal of Economic Surveys, 23 (1): 165-196.

Farrell, D, Puron A, \& Remes, JK. 2005. "Beyond cheap labor: lessons for developing economies. McKinsey Quarterly, November.

Gallup, JL, Sachs JD, \& Mellinger, AD. 1999. Geography and economic development. International Regional Science Review, 22: 179-232.

Gupta, V, \& Subramanian, R. 2008. Seven perspectives on regional clusters and the case of Grand Rapids office furniture city. International Business Review, 17: 371-384.

Kolstad, I, \& Wigg, A. 2012. What determines Chinese outward FDI? Journal of World Business, 47(1): 26-34.

Krugman, PR. 1997. Good news from Ireland: A geographical perspective. In A.W. Gray (Ed), International Perspectives on the Irish Economy. Dublin: Indecon.

Liu, X, Buck, T, \& Shu C. 2005. Chinese economic development, the next stage: outward FDI? International Business Review, 14(1): 97-115.

Moral-Benito, E. 2012. Determinants of economic growth: A Bayesian panel data approach. The Review of Economics and Statistics, 94(2): 566-579. UB

Porter, ME. 1990. The competitive advantage of nations. London: Macmillan. 
Svetličič, M. 2003. "Theoretical context of outward foreign direct investment from transition economies." In Svetličič M. and Rojec M. (Eds.), Facilitating transition by internationalization: Outward direct investment from european economies in transition, Aldershot: Ashgate.

Swann, GMP, Prevezer, M, \& Stout, D. (Eds). 1998. The dynamics of industrial clustering: International comparisons in computing and biotechnology. Oxford: Oxford University Press.

Tanaka K, \& Molnar, M. 2008. What is different about informal finance? Financing of private firms in China. Revue économique, 59(6): 1131-1143

Tolentino, PE. 2010. Home country macroeconomic factors and outward FDI of China and India. Journal of International Management, 16 (2): 102-120.

UNCTAD. 2006. World investment report 2006-FDI from developing and transition economies: Implications for development. New York and Geneva: United Nations.

UNCTAD. 2011. World investment report 2011-Non-equity modes of international production and development. New York and Geneva: United Nations.

UNCTAD. 2012. World investment report 2012-Towards a new generation of investment policies. New York and Geneva: United Nations.

Venables, AJ. 1996. Equilibrium Locations of Vertically Linked Industries. International Economic Review, 37: 341-59.

Wang, C, Hong, J, Kafouros, M, \& Boateng, A. 2012. What drives outward FDI of Chinese firms? Testing the explanatory power of three theoretical frameworks. International Business Review, 21(3): 425-438.

Wang, Y, \& Yao, Y. 2003. Sources of China's economic growth 1952-1999: Incorporating human capital accumulation. China Economic Review, 14: 32-52.

Wei, WX, \& Alon, I. 2010. Chinese outward direct investment: a study on macroeconomic determinants. International Journal of Business and Emerging Markets, 2(4): 352-368.

You, K, \& Sarantis, N. 2012. Structural breaks and the equilibrium real effective exchange rate of China: A NATREX approach. China Economic Review, 23(4): 1146-1163.

Zhang, L. 2004. The roles of corporatization and stock market listing in reforming China’s state industry. World Development, 32(12): 2031-2047. 